\title{
ANTIOXIDANT AND ANTICANCER ACTIVITIES OF HEXANE FRACTION FROM CARICA PAPAYA L. MALE FLOWER
}

\author{
MASRIA PHETHERESIA SIANIPAR*, EDY SUWARSO, ROSIDAH ROSIDAH
}

Department of Pharmacology, Faculty of Pharmacy, University of Sumatera Utara, Medan, Indonesia. Email: masriasianipar12@gmail.com

Received: 05 September 2017, Revised and Accepted: 25 November 2017

ABSTRACT

Objective: This study examined the antioxidant and anticancer potential activities of the hexane fraction from the male flower of Carica papaya L., which is long been known to be a very important source of nutraceutical and pharmaceutical.

Methods: Standard fractioned (fraction) method with phytochemical screening. The antioxidant activity was carried out using the $\alpha, \alpha$-diphenyl- $\beta$ picrylhydrazyl method and the anticancer potential activity was carried out using 3-(4,5-dimethythiazol-. 2-yl)-2,5-diphenyl tetrazolium bromide assay to check the cytotoxic activity on WiDr (colon cancer cell) and Vero cell (normal cell).

Result: Phytochemical screening of the hexane fraction from the male flower of papaya shows a strong sign of triterpenoids and steroids; while the IC50 of antioxidant value was $100.81 \pm 1.180 \mu \mathrm{g} / \mathrm{ml}$. Cytotoxic effect shows that the hexane fraction of papaya male flower had selectivity to WiDr cell (colon cancer cell).

Conclusion: This study provides evidence that $C$. papaya L. male flower possesses antioxidant activity, as well as cytotoxic and chemopreventive properties. It might be beneficial as medicinal plant as an antioxidant and anticancer nutraceutical and pharmaceutical sources.

Keywords: Carica papaya, Antioxidant, $\alpha, \alpha$-diphenyl- $\beta$-picrylhydrazyl, Anticancer, 3-(4,5-dimethythiazol-. 2-yl)-2,5-diphenyl tetrazolium bromide, Hexane, Chemoprevention.

(C) 2018 The Authors. Published by Innovare Academic Sciences Pvt Ltd. This is an open access article under the CC BY license (http://creativecommons. org/licenses/by/4. 0/) DOI: http://dx.doi.org/10.22159/ajpcr.2018.v11i3.22382

\section{INTRODUCTION}

Reactive oxygen species (ROS) are highly reactive species, due to the presence of unpaired valence shell electrons. Free radicals or ROS are regularly and continuously produced as byproducts of normal cellular metabolism in aerobics. Free radical chain reactions are usually produced in the mitochondrial respiratory chain, liver mixed functions, and by drugs or xenobiotic such as synthetic pesticides. In addition, chemical mobilization of fat stores under various conditions such as lactation, exercise, fever, and even infection can cause an increase in radical activity that leads to oxidative stress $[1,2]$.

Oxidative injury now appears the fundamental mechanism underlying a number of human neurologic and other disorders [3] such as neurodegenerative disorders, for example, Alzheimer's disease, Parkinson's disease, multiple sclerosis, Down's syndrome, inflammation, viral infection, autoimmune disorder, gastrointestinal inflammation, ulcer, mutagenesis, and carcinogenesis [4-6]. Moreover, the ROS also initiate the multistage carcinogenesis process starting with the DNA damage and accumulation of genetic events in one or a few lines, which leads to the progressive dysplastic cellular appearance, deregulated cell growth, and finally carcinoma [7].

Cancer is the leading cause of mortality worldwide. According to the cancer reports published by the World Health Organization and the World Cancer Research Fund, the incidence of cancer is still increasing, especially due to diet, environment, and carcinogenic virus infections $[8,9]$.

Cancer is a multistep disease, incorporating physical, environmental, metabolic, chemical, and genetic factors, which play a direct and/or indirect role in the induction and deterioration of cancers. In Indonesia, colon and rectal cancer are ranked fourth of cancer deaths after lung, liver, and stomach cancer every year [10]. Therefore, proper prevention and treatment efforts are needed to reduce the incidence of death from colon cancer. Diet with high consumption of antioxidant-rich fruits and vegetables significantly reduces the risk of many cancer diseases suggesting that confident antioxidants could be effective agents for the inhibition of cancer spread [11].

Doxorubicin is one of the chemotherapeutic agents included in the main class of cytotoxic agents that are anthracyclines that have broadspectrum antitumor activity. However, the use of doxorubicin is restricted because it can cause toxicity in normal cells, cardiotoxicity leading to heart failure [12] so that treatment becomes less effective. In other side, plants have many phytochemicals with various bioactivities including antioxidant, anti-inflammatory, and anticancer activities which are safe [13-15]. One of the useful plants is male papaya (Carica papaya L.) flower. Male papaya flowers have long been known to be a very important source in maintaining public health. Flower papaya males have been studied where the plant part of flower papaya males has high antioxidants. For ages, papaya has been used as a medicinal plant traditionally, due to its antibacterial, antioxidant, anticancer, and antitumor activities [16-18] and is well known for a wide variety of medicinal uses.

By keeping in view all the properties of antioxidants, their use in the treatment of different degenerative and neurological disorders; present research work was designed for the isolation of bioactive components of male flower extracts and assessment of anticancer activity on different cancer cell lines, using different extracts of the male flower of $C$. papaya L. Therefore, the aim of the present study was to investigate the in vitro antioxidant and cytotoxic activity of papaya male flower extracts on human colon cancer cell (WiDr).

\section{METHODS}

Plant material preparation

Fresh papaya male flower was collected from local area of Porsea district (North Sumatera, Indonesia) and authenticated by Herbarium 
Medanense (MEDA) University of Sumatera Utara. Voucher specimen was collected and deposited in the Pharmacognosy Laboratory, Faculty of Pharmacy, University of Sumatera Utara.

\section{Preparation of extract and fractions}

Extraction was done by percolation method using ethanol solvent. $200 \mathrm{~g}$ of powdered papaya male flower is percolated in $1 \mathrm{~L}$ ethanol solvent 24 $\mathrm{h}$, then filtered, do it continuously until the filtrate obtained is clear and colorless. $10 \mathrm{~g}$ concentrated ethanolic extract, then fractioned using hexane solvent to get the hexane fraction $[19,20]$.

\section{Preliminary phytochemical screening}

Phytochemical screening carried out on various papaya male flower hexane fraction included examining the chemical metabolites constituent of alkaloids, flavonoids, glycosides, tannins, triterpenoids, and steroids [21-23].

Measurement of the antioxidant activity using $\alpha, \alpha$-diphenyl- $\beta$ picrylhydrazyl (DPPH)

Analysis of DPPH radical scavenging activity was carried out according to Blois method. 0.5 mM DPPH was added to each sample. A dilution series was prepared for ascorbic acid and hexane fraction. After incubation for $30 \mathrm{~min}$ in the dark condition, and absorbance was taken at $515 \mathrm{~nm}$ and calculated the\%inhibition of DPPH radical [24,25]. Test was carried out in triplicate.

Percentage of inhibition $=$

Absorbancecontrol-Absorbancesample

$$
\text { Absorbance control }
$$

Cytotoxicity on WiDr cell 3-(4,5-dimethythiazol-. 2-yl)-2,5diphenyl tetrazolium bromide (MTT) test

This assay was performed according to Meiyanto et al. (2008). In microplate 96, a WiDr (colon cancer) cells suspension $\left(1 \times 10^{4}\right.$ cells/well) was incubated at $5 \% \mathrm{CO}_{2}, 37^{\circ} \mathrm{C}$. The cells were then rinsed and grown in a new DMEM containing hexane fraction. After incubated for $24 \mathrm{~h}$, the Dulbecco's modified Eagles Media (DMEM) was removed and the cells were incubated again with $100 \mu \mathrm{l}$ DMEM and $10 \mu \mathrm{l}$ MTT solution for 4-6 h. The plate was read using an ELIZA reader at a wavelength $595 \mathrm{~nm}$. The cytotoxicity was obtained by comparing the absorbance between the samples and the control [26].

\section{Statistical analysis}

All the data were expressed as mean \pm standard deviation. The significant difference of data between different groups was compared by ANOVA followed by Duncan's test.

\section{RESULTS}

\section{Phytochemical screening}

Screening results of the hexane fraction of papaya male flowers showed different chemical compound in different extract.

\section{DPPH scavenging activity of free radical}

The result of the radical scavenging capacities determined by DPPH assay is shown in Table 1 .

\section{Cytotoxicity effect on WiDr cell}

The anticancer activity of papaya male flower hexane fraction was investigated using a MTT assay on colon cancer cell (WiDr cell). Fig. 1 shows that the effect of fraction on WiDr cell and normal human cell (Vero cell).

\section{DISCUSSION}

Although papaya has been reported for its benefits and biological activities, little is known scientifically about its male flower antioxidant and anticancer activity. The present study was aimed to reveal the effect of hexane fraction from papaya male flowers on the antioxidant and anticancer potential on WiDr cell (colon cancer cell). Preliminary
Table 1: Total antioxidant capacities of various solvent fractions of the ethanolic extract of papaya male flower

\begin{tabular}{ll}
\hline Solvent & IC50 \\
\hline Hexane fraction & $100.81 \pm 1.180$ \\
Ascorbic acid & $5.173 \pm 0.382$ \\
\hline
\end{tabular}

Table 2: Phytochemical screening result of hexane fraction from papaya male flower

\begin{tabular}{ll}
\hline Screening & Hexane fraction \\
\hline Alkaloids & Negative \\
Flavonoids & Negative \\
Glycosides & Negative \\
Tannins & Negative \\
Triterpenoid/steroids & Positive \\
\hline
\end{tabular}

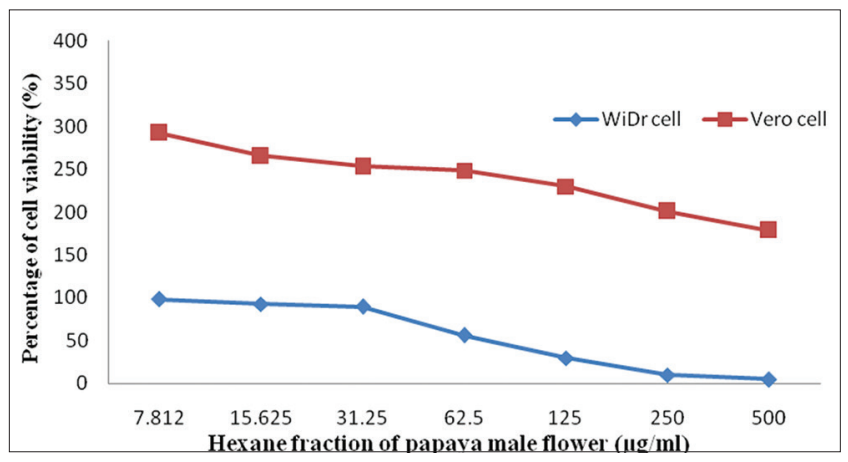

Fig. 1: The cytotoxic effect of papaya male flower hexane fraction on WiDr cell line

phytochemical screening was the first step to do. The phytochemical screening (Table 2) results show that the hexane fraction of papaya male flower revealed the strong presence of triterpenoids and steroids phytochemical constituents.

Free radicals are one of the major factors necessary to cause DNA mutation, which in turn triggers the initiation stage of carcinogenesis [27]. To protect human beings against free radicals problem, it is important to identify the new sources of safe and inexpensive antioxidants of natural origin. Antiradical power of natural sources was measured using the DPPH method which is stable, quick, reliable, and reproducible. The hexane fraction of papaya male flower shows a good potential antioxidant activity (IC50 $=100.81 \pm 1.180$ ). It is very important to point out that a low IC50 value reflects a high antioxidant of the fraction $[28,29]$.

An investigation was done on anticancer properties of papaya leaves significant growth inhibitory activity of the papaya extract on tumor cell lines was observed [16]. Another study shows that the hexane fraction of papaya male flower had a good anticancer effect on breast cancer. In the current study, the effect of hexane fraction of papaya male flower was tested on WiDr cell and Vero cell (normal human cell) using MTT to see the cytotoxic effect. MTT assay study shows that hexane fraction had a good IC50 value on cell viability (IC50: $64.105 \mu \mathrm{g} / \mathrm{ml}$ ). This result indicated that hexane fraction could suppress the growth of WiDr cell. It can happen due to the triterpenoids and steroids compound in the hexane fraction. Another possibility is due to the high antioxidant activity from the hexane fraction of papaya male flower [30,31].

\section{CONCLUSIONS}

From overall, the study of antioxidant and anticancer potential of hexane fraction from papaya (C. papaya L.) male flower could be concluded that papaya male flower is an excellent source of antioxidant 
and is a promising source of potential anticancer source. These findings indicate the medicinal value of papaya in terms of cancer chemotherapy and chemoprevention.

\section{ACKNOWLEDGMENTS}

The authors would like to thank the Faculty of Pharmacy (USU), Yayasan Tenaga Pembangunan Arjuna Laguboti and Iksen, S.Farm., M.Si (USU), for consultant and helpful support in editing the manuscript.

\section{AUTHORS CONTRIBUTION}

All the author have contributed equally

\section{CONFLICTS OF INTERESTS}

Declared none

\section{REFERENCES}

1. Dixit $\mathrm{S}$, Ali H. Antioxidant potential of some medicinal plants of central India. J Cancer Ther 2010;1:87-90.

2. Iqbal S, Younas U, Sirajuddin, Chan KW, Sarfraz RA, Uddin K. Proximate composition and antioxidant potential of leaves from three varieties of Mulberry (Morus sp.): A comparative study. Int J Mol Sci 2012;13:6651-64

3. Atawodi SE. Antioxidant potential of African plants. Afr J Biotechnol 2004:4:128-33.

4. Repetto MG, Llesuy SF. Antioxidant properties of natural compounds used in popular medicine for gastric ulcers. Braz J Med Biol Res 2002;35:523-34.

5. Aruoma OI. Methodological considerations for characterizing potential antioxidant actions of bioactive components in plant foods. Mutat Res 2003;523-524:9-20.

6. Surh YJ, Ferguson LR. Dietary and medicinal antimutagens and anticarcinogens: Molecular mechanisms and chemopreventive potential-highlights of a symposium. Mutat Res 2003;523-524:1-8.

7. Satria D, Silalahi J, Haro G, Ilyas S, Hsb PA. Antioxidant and antiproliferative activities of an ethylacetate fraction of picria fel-terrae lour. Herbs Asian Pac J Cancer Prev 2017;18:399-403.

8. World Health Organization. World Cancer Report 2008. France: IARC; 2008.

9. World Cancer Research Fund. Food, Physical Activity and the Prevention of Cancer: A Global Perspective. USA: America Insititute for Cancer Research; 2007.

10. Indonesia Health Ministry. Stop Kanker: Kementrian Kesehatan RI. Indonesia: Indonesia Health Ministry; 2015.

11. Ghasemzadeh A, Jaafar HZ. Antioxidant potential and anticancer activity of young ginger (Zingiber officinale Roscoe) grown under different $\mathrm{CO}_{2}$ concentration. J Med Plant Res 2011;5:3247-5.

12. Ferreira AL, Matsubara LS, Matsubara BB. Anthracycline induced cardiotoxicity. Cardiovasc Hematol Agents Med Chem 2008;6:278-81

13. Pezzuto JM. Plant-derived anticancer agents. Biochem Pharmacol 1997;53:121-33.

14. $\mathrm{Wu} \mathrm{J}, \mathrm{Wu} \mathrm{Y}$, Yang BB. Anticancer activity of Hemsleya amabilis extract. Life Sci 2002;71:2161-70.

15. Lee JY, Hwang WI, Lim ST. Antioxidant and anticancer activities of organic extracts from Platycodon grandiflorum A. De Candolle roots. J Ethnopharmacol 2004;93:409-15.

16. Otsuki N, Dang NH, Kumagai E, Kondo A, Iwata S, Morimoto C. Aqueous extract of Carica papaya leaves exhibits anti-tumor activity and immunomodulatory effects. J Ethnopharmacol 2010;127:760-7.

17. Adesuyi AO, Ipinmoroti KO. The nutritional and functional properties of the seed flour of three varieties of Carica papaya. Curr Res Chem 2011:3:70-5.

18. da Silva CR, Oliveira MB, Motta ES, de Almeida GS, Varanda LL, de Pádula $\mathrm{M}$, et al. Genotoxic and cytotoxic safety evaluation of papain (Carica papaya L.) using in vitro assays. J Biomed Biotechnol 2010;2010:197898.

19. Ditjen PO. Farmakope Indonesia. $4^{\text {th }}$ ed. Jakarta: Depkes RI; 1995. p. 896-8.

20. Basset J, Denney RC, Jeffrey GH, Mendham J. Buku Ajar Vogel Kimia Analisis Kuantitatif Anorganik. 4 ${ }^{\text {th }}$ ed. Jakarta: EGC; 2003.

21. Depkes RI. Materia medika. Ditjen POM 1995;6:297-307.

22. Farnsworth NR. Biologycal and phytochemical screening of plants. J Pharm Sci 1996;55:225-76.

23. Harbone JB. Metode fitokimia. India Testing Board 1987;2:6-49.

24. Burali S, Kulkarni AR. Antioxidant status of fruit peel of Citrus reticulata essential oil on 1,2 dimethylhydrazine induced rat colon carciogenesis. Res J Pharm Biol Chem Sci 2013;4 Suppl 1:340-9.

25. Rosidah R, Yam M, Sadiun A, Asmawi M. Antioxidant potential of Gyunura procumbens. Pharm Biol 2008;46:616-25.

26. Meiyanto E, Nugroho AE, Hermawan A, Putri DD, Novika A. Combinational effects of hexane insoluble fraction of Ficus septica Burm. F and doxorubicin chemotherapy on T47D breast cancer cells. Asian Pac J Trop Biomed 2012;2:1-6.

27. Johnson IT. New approaches to the role of diet in the prevention of cancers of the alimentary tract. Mutat Res 2004;551:9-28.

28. Koleva II, van Beek TA, Linssen JP, de Groot A, Evstatieva LN. Screening of plant extracts for antioxidant activity: A comparative study on three testing methods. Phytochem Anal 2002;13:8-17.

29. Chakraborty M, Karmakar I, Haldar S, Nepal A, Haldar PK. Anticancer and antioxidant activity of methanol extract of Hippophae salicifolia in EAC induced Swiss albino mice. Int J Pharm Pharm Sci 2015;7:180-4.

30. Nisa S, Bibi Y, Waheed A, Zia M, Sarwar S, Ahmed S, et al. Evaluation of anticancer activity of Debregeasia salicifolia extract against estrogen receptor positive cell line. Afr J Biotechnol 2011;10:990-5

31. Deepika KS, Rama NK, Muthuraman MS, Natesan R, Raj D, Pemaiah B. Evaluation of in vitro anticancer potential of ethanolic extract and different fractions of Caesalpinia bonduc (L) Roxb seeds. Int J Pharm Pharm Sci 2014;6:311-4. 